\title{
Dampak Media Sosial Terhadap Konflik di Masyarakat
}

\author{
Suyati ${ }^{\# 1}$ \\ \# Pendidikan Agama Islam, Fakultas Agama Islam, Universitas Ahmad Dahlan, Indonesia \\ Jl. Ringroad Selatan, Kragilan, Tamanan, kec. Banguntapan, Bantul DIY \\ 1 suyati1700331014@webmail.uad.ac.id
}

\begin{abstract}
In life in society, social media is not new anymore. Various ages, young and old small adults have tasted this type of technology that is growing. Social media usher in a new life order. There are many things in the use of this media that lead to benefits, but not a few things that cause harm from the unwise use of social media. The function that existed before has undergone a shift as the media developed. What used to be only a medium of communication and a means of sharing is now even more sophisticated. This is less balanced in the community. Many people are indifferent in using this. There are also many conflicts in the community from the existence of social media. Starting from the spread of hoaxes, bullying to crimes in the form of criminals. Even in its use some reach high doses to the point of addiction. In minimizing the occurrence of conflict from social media, it is necessary to balance the use of social media wisely so that people can reap the benefits of the use of social media, leading to a good life order, so that the potential that exists in society is always developed and does not occasionally stagnate or stagnate.
\end{abstract}

Keywords- social media, conflict, society, wise.

Abstrak- Dalam kehidupan di masyarakat media sosial bukan hal baru lagi. Berbagai usia, tua muda kecil dewasa telah mencicipi jenis teknologi yang semakin berkembang ini. Media sosial mengantarkan masyarakat kepada tatanan kehidupan yang baru. Banyak hal dalam penggunaan media ini yang menimbulkan kemanfaatan, tapi tidak sedikit juga hal yang mengakibatkan kemudharatan dari ketidak bijaknya pemakaian media sosial. Fungsi yang ada dulu semakin mengalami pergeseran seiring berkembangnya media ini. Yang dahulu hanya sebagai media komunikasi dan sarana berbagi sekarang lebih canggih lagi. Hal ini kurang terimbangi di lingkungan masyarakat. Banyak masyarakat yang acuh-tak acuh dalam menggunaan ini. Banyak pula terjadi konflik ditengah masyarakat dari adanya media sosial. Mulai dari tersebarnya hoax, bullying hingga tindak kejahatan dalam bentuk kriminal. Bahkan dalam penggunaannya ada yang mencapai dosis tinggi hingga berada pada titik kecanduan. Dalam meminimalisisr terjadinya konflik dari media sosial, perlu di imbangi pemanfaatan media sosial dengan bijak agar masyarakat dapat memetik kemanfaatan hasil pemakaian media sosial, mengantarkan kepada tatanan kehidupan yang baik, sehingga potensi yang ada pada masyarakat selalu dikembangkan dan tidak sesekali terjadi kemandegan atau kejumudan.

Kata Kunci- media sosial, konflik, masyarakat, bijak

\section{PENDAHULUAN}

Indonesia merupakan Negara Multikultural dengan memiliki segudang keberagaam mulai dari Agama, ras, suku dan budaya. Disisi keberagaman yang dimiliki Indonesia, tidak bisa di bantah bahwa Negara telah dan sedang mengalami perkembangan pesat dibidang globalisasi. Dimana yang dulu masih banyak masyarakat yang notabennya menekuni bidang agraria, hingga masuknya bidang industri dan hingga sekarang yang lebih mendominasi adalah perkembangan globalisasi. Adanya perkembangan globalisasi yang ditandai dengan kemajuan teknologi sudah menjadi hal lumprah dalam tatanan masyarakat akan tetapi kebanyakan masyarakat sekarang dalam pemanfaatan teknologi tidak mengimbanginya dengan literasi. Banyaknya aplikasi-aplikasi digital seperti media sosial yang hampir setiap orang menggunakannya hanya dijadikan sebagai media instan tanpa melihat dampak negatif akibat tidak bijaknya dalam penggunaan media tersebut.

Media sosial yang sangat beragam kini telah mengalami fungsi pergeseran dalam kehidupan. Hal yang seharusnya sulit bisa dijadikan mudah dengan adanya media sosial seperti halnya komunikasi, kini dalam penggunaannya tidak sedikit pula yang membumbuhi dengan caci maki, serta perkataan yang seharusnya tidak dilontarkan lewat media. Kemudian ada juga yang menjadikan media sosial sebagai kepentingan golongan seperti partai yang memaksa anggotanya untuk membenarkan suatu hal walaupun itu tidak benar. Bahkan kekerasan lewat media sosialpun sekarang sudah sering dijumpai. Tidak hanya itu, smart reader sekarang minim sekali dalam penggunakan media sosial. Banyak media sosial yang disalah gunakan mengakibatkan kompleksnya konflik yang ada di masyarakat. Berniat baik menyebarkan berita tetapi tidak mencari kebenaran realita dalam kehidupan yang ada menjadi berita hoax tersebar dimana-mana. Hal tersebut merupakan isu-isu permasalahan penggunaan media sosial yang terjadi ditengah masyarakat dengan latar belakang dan sudut yang berbeda setiap individunya.

Konflik-konflik yang ada di masyarakat bisa terjadi karena faktor persamaan dan perbedaan kepentingan sosial, 
faktor kemajemukan Indonesia yang memiliki bermacammacam suku, agama, ras dan budaya yang dalam penyikapan suatu hal pasti berbeda, bisa juga karena adanya kesempatan ataupun keterpaksaan, dan bisa pula karena faktor-faktor yang lain. Jika dalam penggunaan media sosial tidak diperhatikan dengan baik, tentu ini akan menjadikan potensi masyarakat yang harusnya bisa unggul tetapi menjadi jumud, dan tidak berkembang karena acuh tak acuh dengan bermedia sosial yang bijak. Dalam artikel ini penulis akan memaparkan beberapa dampak media sosial terhadap konflik di masyarakat serta bagaimana cara bermedia sosial yang bijak. Agar masyarakat semakin paham dengan penggunaan media sosial, serta tidak ada lagi konflik besar yang beragam dan berkelanjutan karena adanya media sosial. Tercipta masyarakat yang damai, saling menghormati serta bertolerasi dalam hal apapun.

\section{TINJAUAN PUSTAKA}

\section{A. Media sosial}

Menurut Van Dijk yang disebut media sosial yaitu platform media yang fokus pada esksistensi pengguna untuk memfasilitasi dalam berbagai aktivitas [1]. Selain itu media sosial juga dikatakan sebagai kumpulan perangkat lunak yang membantu individu dalam berkumpul, berbagi, berkomunikasi serta berkolaborasi. Pada intinya yang dinamakan media sosial yaitu media yang dapat membantu dalam berkomunikasi dua arah dalam bentuk visual maupun audio visual. [2]

Nasrullah, mengategorikan jenis media sosial menjadi enam, yaitu:

1. media jejaring sosial, yakni sarana yang biasanya dinakan untuk melakukan hubungan sosial secara virtual.

2. Jurnal online (blog), media sosial yang sering digunakan untuk mengunggah aktivitas keseharian dalam bentuk tulisan, gambar, maupun lainnya. Sebagai contoh: wordpress atau blogspot.

3. Jurnal online sederhana, media ini digunakan untuk menulis atau mempublikasikan aktivitas dan pendapatnya. Contohnya, twitter.

4. Media berbagi, jenis media sosial yang memberikan fasilatas kepada kenggunanya untuk berbagi media mulai dari dokumen, audio, video, gambar dan lain-lain.

5. Penanda sosial, yaitu media yang bekerja untuk mengorganisasikan, menyimpan, mengelola dan mencari informasi secara online.

6. Media konten bersama, adalah media yang kontennya merupakan hasil kolaborasi dari para pengguna. Seperti wikipedia. [3]

\section{B. Konflik}

Kata konflik berasal dari configure, conflictum (Bahasa Yunani) yang artinya benturan. Maksudnya kata tersebut juga merujuk pada semua bentuk benturan, tabrakan, ketidakserasian, perkelahian, pertentangan oposisi serta interaksi yang antagonis pertentangan. Konflik juga diartikan sebagai pertentangan yang diekspresikan diantara dua belah pihak atau lebih yang mengalami percecokan sehingga mengakibatkan objek konflik menjadi keluaran konflik. Secara gampangnya yang disebut konflik yaitu perselisihan, pertentangan, ataupun perbedaan pendapat yang terjadi diantara seseorang dengan orang lain, atau dalam kelompok tertentu yang belum menimbulkan kesepahaman dan kesepakatan bersama dari kedua belah pihak yang terkena konflik.

dapun macam-macam konflik adalah sebagai berikut: [4]

1. konflik intrapersonal yakni konflik yang ditimbulkan dari dalam diri seseorang.

2. Konflik interpersonal, yaitu konflik yang terjadi antar individu. Konflik ini bisa terjadi ketida ada kesalahfahaman, perbedaan pendapat, sikap dan lain sebagainya yang timbul ketika proses pencapaian sebuah tujuan bersama.

3. Konfilik intragroup, yaitu konflik antar anggota yang berada dalam suatu kelompok. Contonya konflik yang terjadi pada beberapa guru dalam musyawarah Guru Mata Pelajaran (MGMP).

4. Konflik intergroup, yaitu konflik yang terjadi antar kelompok.

5. Konflik intraorganisasi, yakni konflik yang terjadi antarbagian dalam korganisasi.

6. Konflik interorganisasi, yaitu konflik yang terjadi antar organisasi.

Terjadinya sebuah konflik dapat di minimalisir atau dikelola dengan adanya manajemen konflik. Adapun yang dimaksud dengan manajemen konflik yaitu sebuah prinsip, cara, teori, serta konsep dalam mengatur aktivitas penyelesaian konflik dimana ditjukan untuk mencapai kesepakatan dan tujuan bersama yang efektif dan efisien diantara individu. Sering kali konflik hanya dinilai berdampak negatif. Tenyata pada realitasnya konflik memiliki dampak positif dan negatif. Dampak positif konflik diantaranya sebagai berikut:

1. Menimbulkan kemampuan intropeksi diri

2. Meningkatkan kinerja setiap individu.

3. Pendekatan yang lebih baik. Maksudnya konflik menimbulkan seseorang akan lebih berhati-hati dalam menjalin interaksi dengan orang lain.

4. Mengembangkan alternatif yang lebih baik. Semakin banyak permasalahan yang dihadapi, semakin membuat seseorang dapat mengembangkan nalar kritisnya ketika dibenturkan dengan kompleknya permasalahan.

Adapun dampak negatif yang ditimbulkan antara lain:

1. subjektif dan emosional. Pada umumnya, pihak yang sedang terkena konflik seringkali emosional dan subjektif dalam penilaian.

2. Selalu merasa bahwa dirinya benar. Ketika subjektif dan emosional sudah terjadi pada diri seseorang yang terkena konflik seringkali akan menganggap dirinya yang paling benar.

3. Saling menjatuhkan. Konflik yang berkelanjutan bisa mengakibatkan saling benci bahkan saling menjatuhkan. 
4. Stress.Stres terjadi apabila konflik berkepanjangan sehingga menimbulkan ketidakseimbangan fisik dan psikis.

5. Frustasi. Ketika seseorang yang terkena konflik tidak bisa memanajemen dirinya, lama-kelamaan akan menyebabkan frustasi. [5]

C. Konflik Masyarakat

Sejatinya konflik masyarakat merupakan sebuah pertentangn, pertikaian, ataupun permasalahan yang ditimbulkan akibat hubungan sosial masyarakat. Konflik masyarakat sangatlah beragam. Ada konflik yang ditimbulkan karena faktor ekonomi, sosial, politik, agama, teknologi, maupun prespektif atau cara pandang dari seorang individu kesesuatu hal.Konflik masyarakat sering disebut konflik sosial. Adapun yang dimaksud dengan konflik sosial yaitu bentuk interaksi sosial dalam masyarakat yang ditandai dengan sikap saling mengancam hingga menghancurkan. [6]

\section{METODE PENELITIAN}

Penelitian ini merupakan analisis pustaka dengan tinjauan pustaka. Pengumpulan data dilakukan melalui penelusuran literatur ilmiah secara sistematis pada artikel-artikel jurnal dan dokumen yang membahas secara signifikan dan berkaitan dengan tema penelitian ini. Konteks yang menjadi objek penelitian ini adalah studi kasus di masyarakat Indonesia, maka data-data yang dielaborasi sangat berkaitan erat pada bagaimana dampak media sosial terhadap konflik di masyarakat dapat dianalisis secara mendalam. Selanjutnya setelah dilakukan proses pengumpulan data dan analisis, maka peneliti memberikan kesimpulan akhir sebagai penutup hasil penelitian ini.

\section{HASIL DAN PEMBAHASAN}

\section{A. Media Sosial (Pengertian, jenis, ciri-ciri dan fungsi} media sosial)

Sejauh ini perkembangan teknologi telah menambah minat baru bagi masyarakat. Tak heran sekarang banyak masyarakat menggunakan teknologi terkhusus media sosial untuk banyak keperluan. Mulai dari anak-anak hingga orang tua semua mencicipi apa itu media sosial. Bahkan ada yang menggunakan media sosial sebagai sarana belajar, dan dianggap sebagai guru. Ada pula yang sampai tidak terkontrol penggunaannya hingga mengakibatkan munculnya konflik. Sejatinya media sosial merupakan teknologi web baru berbasis internet yang memberikan kemudahan seseorang untuk berkomunikasi, berpartisipasi, saling berbagi dan membentuk jaringan secara online. [7] Seringkali media sosial dikatakan sebagai media online yang mendukung interaksi sosial yang mampu mengubah komunikasi menjadi dialog interaktif.

Menurut Adreas Kaplan dan Michael Haenlein media sosial adalah sebuah kelompok aplikasi yang berbasis internet yang membangun diatas dasar ideologi dan teknologi Web 2.0, dan yang memungkinkan penciptaan dan pertukaran user-generated content. [8] Sedangkan Shirky berpendapat media sosial dan perangkat lunak adalah alat yang digunakan untuk meningkatkan kemampuan pengguna untuk berbagi, bekerja sama, diantara pengguna dan melakukan suatu hal yang diinginkan diluar kerangka organisasi. Dengan adanya media sosial ini manusia dapat saling berbagi ide, bekerjasama, dan berkolaborasi untuk menciptakan kreasi, berpikir, berdebat, membangun komunitas, mencari pasangan dan lain sebagainya. [9] Dari pengertian-pengertian diatas dapat di simpulkan bahwa yang disebut media sosial yaitu proses yang dilakukan oleh seseorang dengan menggunakan media sebagai sarana berbagi informasi, berdikusi, betukar ide, berkreasi, berfikir, berdebat menambah teman secara mudah dengan internet dan aplikasi yang ada di anroid/ handpone.

Seiring perkembangan teknologi media sosialpun ikut berkembang dengan cepat. Berbagai macam media sosial sekarang sudah tersedia untuk memudahkan manusia dalam menjalani aktivitasnya. Adapun jenis jenis media sosial adalah sebagai berikut:[10]

1. Aplikasi berbagi video sangat efektif untuk menyebar berbagai macam konten yang ingin disebarkan/ dibagikan secara lebih luas. Aplikasi yang dimaksud seperti YouTube, Vimeo, dan DailyMotion.

2. Aplikasi Media Sosial Mikroblog Aplikasi ini seperti Twitter dan Tumblr

3. Aplikasi Media Sosial Berbagai Jaringan Sosial Aplikasi jenis ini sudah banyak pengguna yang menggunakannya, seperti Facebook, Google Plus, serta Path. Aplikasi media sosial berbagai jaringan sosial ini memiliki kelebihan dan kekurangan masing-masing dalam penggunaannya.

4. Aplikasi Berbagai Jaringan Profesional

Aplikasi ini banyak digunakan oleh kalangan akademi, mahasiswa para peneliti, pegawai pemerintah dan pengamat. Dengan adanya aplikasi jenis ini memudahkan mereka dalam mengerjakan tugas-tugas yang dibebankannya. Contoh aplikasi jenis ini yang popular yaitu Linkedln, Scribd dan Slideshare.

5. Aplikasi Berbagai Foto

Beberapa aplikasi jenis ini yang populer yaitu Pinterest, Picasa, Flickr dan Instagram.

Ciri-ciri yang melekat pada media sosial yakni konten yang disampaikan atau dibagikan bisa tersebar luas dan tidak terbatas; Pesan disampaikan secara online, isinya muncul melalui gatekeeper dan idak ada gerbang penghambat; Kontendapat diterima secara online dengan lebih cepat; Media sosial menjadikan pengguna sebagai creator dan aktor untuk mengaktualisasikan dirinya; dalam konten meia sosial terdapat aspek fungsional seperti identitas, pinteraksi, berbagi, kehadiran, relasi, reputasi dan group atau kelompok.[11]

Dengan beragamnya jenis media sosial tentu memiliki fungsi yang beragam pula. Pada umumnya media sosial digunakan untuk saling berkomunikasi, berbagi dan berpartisipasi. Karena hal ini dianggap mudah bisa dilakukan 
kapanpun dan dimanapun. Tenia berpendapat fungsi media sosial dibagi menjadi lima, yaitu mencari berita, informasi dan pengetahuan, untuk sarana hiburan, komunikasi daring, menggerakkan masyarakat, serta sebagai sarana berbagi.[12] Tenia menganggap media sosial sebagai sarana memperoleh informasi, berita dan pengetahuan lebih mudah dan cepat dibandingkan media televisi maupun media sebangsanya. Disisi lain juga mudah untuk memperoleh hiburan dengan menggunakan banyak platform yang telah siap untuk di gunakan. Hal ini bisa digunakan banyak orang ketika dalam posisi sedih, stress, bosan dan sebagainya. Karena tidak bisa dipungkiri bahwasanya setiap orang pasti memiliki masalah, dan perasan pun selalu berubah, bisa ketika dalam posisi senang kemudian berubah sedih dan tentu membutuhkan sarana untuk menghibur dirinya agar bisa keluar dari zona sedihnya. Selain untuk komunikasi personal juga, media sosial bisa digunkan untuk menggerakkan masyarakat. Karena mungkin terhalang jarak dan keterbatasan waktu media sosial menjadi solusi untuk menggerakan banyak masyarakat dalam satu tujuan tertentu. Dan yang terakhir media sosial juga menjadi sarana berbagi, baik berbagi ilmu pengetahuan, informasi, berita, gambar maupun yang lainnya.

Pendapat lain dari McQuail bahwa fungsi utama media sosial untuk masyarakat yaitu sebagai informasi yang didalamnya menekankan inovasi, adaptasi dan kemajuan. Kemudian berfungsi juga sebagai korelasi (menjelaskan menafsirkan dan mengomentari informasi, mengedepankan norma, untuk koordinasi dan membentuk kesepakatan). Fungsi kesinambungan seperti untuk meningkatkan dan melestarikan nilai-nilai. Sebagai hiburan, dan sebagai mobilisasi (mengkapanyekan tujuan masyarakat dalam berbagai bidang, agama, politik ekonomi dan sebagainya).[13]

Ada juga yang berpendapat bahwa Fungsi media sosial meliputi :

1. Untuk memperluas interaksi sosial manusia menggunakan internet dan teknologi web.

2. Untuk mentransformasi praktik komunikasi searah media siaran dari satu institusi media ke banyak audience menjadi praktik komunikasi dialogis antar banyak audience.

3. Untuk mendukung demokratisasi pengetahuan dan informasi.

Informasi Teknologi (IC) yang berasal dari handpone kemudian terhubung dengan internet telah juga telah merubah pola belajar, budaya, kehidupan sosial, keterlibatan politik serta cara pandang pada seseorang.[14] Dan pada intinya media sosial memiliki banyak fungsi tergantung pada pribadi seseorang yang menggunakannya. Media sosial akan berdampak positif jika penggunaannya sesuai dengan yang dibutuhkan, tidak berlebihan hingga mengakibatkan ketagihan.
B. Konflik Masyarakat (pengertian, macam-macam dan penyebabnya)

Konflik adalah gejala sosial yang hadir dalam kehidupan sosial. Konflik dapat muncul dalam setiap ruang dan waktu dimana saja dan kapan saja. Secara etimologi Istilah "konflik" berasal dari bahasa latin con yang artinya bersama dan fligere yang berarti benturan atau tabrakan.[15] Dalam pengertian lain konflik adalah percekcokan, perselisihan dan pertentangan. [16] Sedangkan konflik sosial yaitu sebuah pertentangan yang berkaitan dengan kehidupan dalam masyarakat. [17] Dapat disimpulkan bahwa Konflik sosial adalah bentuk interaksi satu pihak dengan yang lainnya ditengah-tengah kehidupan bermasyarakat yang ditandai dengan adanya sikap saling menekan, mengancam dan menghancurkan. Hal yang mendorong terjadinya konflik yaitu persamaan dan berbedaan kepentingan sosial.

Menurut Soerjono Soekanto konflik sosial dibagi menjadi lima bentuk, yaitu:[18]

1. Konflik individu atau pribadi yang terjadi karena perbedaan pandangan dan sebagainya.

2. Konflik rasial, yaitu konflik yang timbul karena perbedaan ras.

3. Konflik atau pertentangan antar kelas sosial. Ini disebabkan adanya perbedaan kepentingan antar kelas sosial.

4. Konflik politik, yaitu konflik yang terjadi karena adanya kepentingan serta tujuan seseorang maupun kelompok.

5. Konflik yang bersifat internasional. Adalah konflik yang terjadi karena perbedaan kepentingan dan berpengaruh kepada kedaulatan disuatu negara.

Pada dasarnya konflik sosial disebabkan karena faktor kemajemukan. Faktor ini dibagi menjadi dua yakni kemajemukan horizontal dan kemajemukan vertikal. Konflik yang timbul Kemajemukan horizontal yaitu pertentangan yang timbul karena perbedaan kultural seperti suku bangsa, agama, ras, budaya, pekerjaan, profesi dan lain-lain. Sedangkan yang timbul dari kemajemukan vertikal adalah kesenjangan sosial berdasarkan kekayaan, pendidikan maupun kekuasaan.

\section{Dampak Media sosial}

Penggunaan media sosial yang berlangsung dalam masyarakat tentu memiliki dampak. Pada kenyataannya media sosial mampu membentuk pandangan atau opini seseorang tentang pribadinya sendiri dalam menghadapi kehidupan sehari-hari. Seperti kehadiran internet yan dapat berdampak atau merubah seseorang yang menjadikan media sosial sebagai bahan mencari informasi didunia maya, hingga menjadikan apa yang mereka liat menjadi bahan tiruan baik dalam berfikir maupun bertindak. [19] Dampak media sosial ada yang bernilai positif ada pula yang bernilai negatif. Dampak yang dirasakan kebanyakan dari masyarakat termuat dalam poin berikut :

\section{Dampak positif media sosial}

a. Memudahkan seseorang untuk berinteraksi dengan orang lain. Dalam hal ini tentu kita dimudahkan dalam 
berinteraksi karena banyak jenis media sosial yang bisa dimaksimalkan seperti whatApps, instagram, facebook, twitter maupun yang lainnya.

b. Memperluas pergaulan. Ketika media sosial digunakan secara bijak dalam berkomunikasi tentu juga akan berdampak positif terhadap seseorang yang ingin mendapatkan teman baru, pasangan hidup, maupun teman kerja. Meski jangkauanya jauh tetap bisa di akses secara mudah.

c. Jarak dan Waktu bukan penghalang Jarak dan waktu tidak lagi menjadi alasan ketika adanya media sosial. Semua terasa mudah dan dapat terjangkau kapanpun dan dimanapun ketika ingin beinteraksi dengan seseorang.

d. Lebih mudah dalam mengekspresikan diri Media sosial bisa dimanfaatkan untuk sarana mengekspresikan diri bahkan ketika seseorang biasanya gugup dalam penyampaian pendapat, mereka dapat menyuarakan secara bebas. Orang yang biasanya pemalu, bisa dengan enteng mengeluarkan uneg-unegnya di media sosial.

e. Penyebaran Informasi dapat berlangsung secara cepat. Dengan media sosial siapapun dapat menyebarkan informasi dengan mudah tidak terhalang oleh waktu. Orang lainpun akan muda menerima informasi yang tersebar di media sosial kapan saja.

f. Biaya lebih murah. Jika dibandingkan dengan media lainnya, media sosial memerlukan biaya yang lebih murah karena kita hanya perlu membayar biaya internet untuk mengakses media sosial.

Selain yang disebutkan diatas, dampak positif dari adanya media sosial ditengah masyarakat juga memudahkan masyarakat untuk menambah ilmu pengetahuan dan teknologi, selain itu bisa dimanfaatkan juga untuk sarana mengembangkan diri. Dikatakan demikian karena dengan berinteraksi akan menerima umpan balik antara satu dan yang lainnya yang bisa dilecutkan sebagai sarana berkembang menjadi lebih baik. Tidak sampai disitu bahwasanya masyarakat yang sangat menjaga kemanfaatan dari dekatnya media sosial juga bisa mengambil peluang sebagai pendukung usahanya dalam dunia jual beli. Misalnya dalam penawaran produk atau jasa secara online.[20]

\section{Dampak negatif media sosial}

Selain memiliki dampak yang baik bagi masyarakat tentu jika pemakaian media sosial tidak semestinya juga akan berdampak negatif. Adapun dampak negatif media sosial dalam masyarakat diantaranya:

a. Menjauhkan orang-orang yang sudah dekat dan sebaliknya
Hal ini akan terjadi ketika penggunaan media sosial sangat berlebihan dan tidak bisa terkontrol. Ketika semua dihadapkan dengan media sosial dan lupa akan dunia nyata, maka potensi terabaikan orang-orang yang ada didekat kita akan besar.

b. Interaksi yang bersifat tatap muka langsung menurun.

Karena mudahnya berinteraksi dengan media sosial maka seseorang akan cenderung malas untuk bertemu langsung dengan orang lain.

c. Membuat orang-orang menjadi kecanduan terhadap internet

Dengan kepraktisan dan kemudahan menggunakan media sosial, maka orang-orang akan semakin ketergantungan dan lama-kelamaan menjadi kecanduan terhadap dunia maya/ internet.

d. Sangat rentan terhadap pengaruh buruk orang lain

Seperti halnya dalam kehidupan nyata, jika kita tidak pandai menyeleksi lingkungan kita, siapa yang kita jadikan teman maka kita akan rentan terhadap pengaruh buruk yang ada disekeliling kita.

e. Masalah privasi

Dalam hal ini ketika kita tidak memperhatikan apa yang kita share lewat media sosial dengan baik maka apapun yang diterima masyarakat bisa disalahgunakan. Oleh karenanya hendaknya kita lebih berhati hati dalam mengunggah hal-hal yang bersifat privasi.

f. Dapat menimbulkan konflik

Dengan media sosial, siapapun bebas dalam berinteraksi, berpendapat, bertukar ide dan gagasan maupun yang lainnya. Akan tetapi ketika ini dilakukan dengan dosis yang tinggi tanpa ada kontrol maka juga bisa membuahkan konflik ditengah masyarakat. Baik itu salah paham, penipuan, kekerasan virtual, kejahatan maupun yang lainnya. [21]

Dari dampak positif dan negatif yang telah terpaparkan sebenarnya hanya mewakili dari apa yang dirasakan masyarakat, dan belum semua tercakup didalamya karena hal ini sangat kompleks bahwasanya setiap individu berbeda dalam merasakan dan menyikapinya. Sebenarnya adanya dampak ini tergantung pada pemakaian pribadi seseorang. Jika mereka mampu membatasi dan menggunakannya untuk keperluan yang baik tentu akan menjadi sarana manfaat bagi diri dan juga untuk orang lain. Tetapi jika dalam penggunaannya tidak memperhatikan etika dan dosis tertentu pasti akan mengakibatkan suatu konflik atau kendala yang tidak membawa kebermanfaatan. Bahkan bisa menjadi mudharat bagi banyak orang.

\section{Dampak Media Sosial terhadap konflik dimasyarakat}


Karena canggihnya media sosial yang digunakan sekarang mengakibatkan kompleksnya permasalahan yang dihadapi masyarakat pengguna media sosial. Adapun permaslahan yang sering ditemui yaitu hoax, cyber-hate dan cyber-bullying.

1. Hoax, menyebarkan berita yang tidak benar melalui media sosial.

2. Cyber-hate, yaitu kejahatan yang dilakukan secara online menggunakan media sosial.

3. Cyber bullying adalah bentuk bullying yang dilakukan secara online. Ini biasanya terjadi dimedia sosial seperti whatApps, facebook, instagram maupun yang lainnya. Berbeda dengan bullying dalam kehidupan nyata atau sering disebut bullying tradisional, cyber-bullying ini dilakukan tanpa ada batasan ruang dan waktu. Bisa dilakukan kapan saja, dimana saja dan oleh siapa saja. Bentuk-bentuk dari cyber-bullying adalah sebagai berikut:

1. Pelecehan atau provokasi emosi adalah bentuk bullying dengan cara mengirimkan pesan yang mengancam atau menyerang, berbagi aib atau foto yang tidak layak ditampilkan di media sosial, serta postingan yang mengundang amarah di jejaring sosial.

2. Fitnah, menyebarkan berita yang palsu atau tidak benar adanya

3. Penyulut kemarahan, memancing perkelahian dengan cara menggunakan bahasa yang ekstrim

4. Mencuri identitas seseorang dengan membajak akun

5. Pengecualian, yaitu meninggalkan seseorang dengan sengaja

6. Meminta secara paksa serta mengirimkan video seseorang yang berbau seksual.[22]

E. Menggunakan Media Sosial dengan bijak

Dengan banyaknya menyita perhatian, media sosial hendaknya bisa kita manfaatkan sedemikian rupa. Media sosial harus kita gunakan dengan bijak. Berikut ada beberapa hal yang menjadi acuan dalam mengambil kemanfaatannya secara bijak. [23]

1. Lindungi informasi pribadi. Bijaklah dalam berbagi informasi ketika menggunakan media sosial. Mengupload foto atau mengeshare hal pribadi kita ke publik bisa menjadi bumerang untuk kita ketika tidak berhati-hati. Mungkin maksud kita hanya sekedar mengeshare tetapi bisa juga ada orang lain yang memanfaatkan informasi tersebut untuk kejahatan. Oleh karena itu harus senantiasa berhati-hati dan berwaspada, berfikir sebelum mengunggah sesuatu ke media sosial.

2. Memiliki etika dalam berkomunikasi. Dalam berkomunikasi hendaknya menggunakan bahasa yang sopan dan mudah dimengerti. Jangan menggunakan kata yang sifatnya deskriminasi pada seseorang atau suatu kelompok tertentu. Jangan lupakan etika berkomunikasi agar sesuatu yang tidak diinginkan itu tidak terjadi.

3. Hindari penyebaran SARA dan pornogafi. Pastikan apa yang kita share atau unggah tidak berhubungan dengan SARA dan pornogafi. Pilih dan sebarkan informasi yang bermanfaat bagi orang banyak dan tidak menimbulkan konflik antar individu di jejaring sosial.

4. Menghargai karya orang lain. Jika kita mengunggah atau mengshare foto, gambar, video, tulisan, maupun sejenisnya milik orang lain hendaknya kita mencantumkan sumber informasi tersebut sebagai bentuk penghargaan terhadap karya orang lain. hidari hanya mengcopy paste dan langsung unggah tanpa mencantumkan sumber. Biasakan croscek kebenaran sebelum menyebarkan informasi, agar informasi yang disebarkan valid, no hoax.

5. Biasakan membaca sebelum menilai. Ini yang terjadi pada kebanyakan masyarakat sekarang yang terkadang membaca berita hanya sekilas saja dan langsung menyimpulkan. Hal ini mengakibatkan minimnya smart reader. Tidak sedikit juga masyarakat yang hanya ikutikut berkomentar pada suatu berita yang sedang buming tanpa mengecek kembali berita tersebut. Tentu ini harus dihindari dan lebih bijak lagi dalam menyebarkan berita.

6. KESIMPULAN

Media sosial yaitu proses atau kegiatan yang dilakukan seseorang dengan sebuah media yang dapat digunakan untuk berbagi informasi, betukar ide, berkreasi, berfikir, berdebat menambah teman secara mudah dengan sebuah aplikasi online yang ada dapat digunakan dengan telepon genggam.

Media sosial memiliki banyak fungsi tergantung pada pribadi seseorang yang menggunakannya. Bisa berfungsi sebagai media komunikasi, saling berbagi informasi atau berita, sarana menghibur diri maupun yang lainnya. Fungsifungsi yang diupayakan berdampingan dengan dampak yang timbul dari penggunaan media sosial. Yakni dampak positif seperti mudah memperluas jaringan pertemanan, bisa memanfaatkan sebagai sarana bisnis online, berbagi ilmu pengetauan maupun berita dengan cepat dan mudah dan lainlain. Adapun dampak negatif seperti kecanduan, menurunnya interaksi sosial, dan bisa menimbulkan konflik kesengajaan maupun kesalahpahaman.

Masalah yang sering terlihat dimasyarakat berkenaan media sosial yaitu penyebaran hoax, maraknya cyber-hate dan cyber bullying. Dengan demikian kita harus berupaya memanfaatkan teknologi media sosial dengan bijak agar memperoleh banyak kemanfaatan baik untuk diri sendiri maupun orang lain. Langkah ini bisa dimaksimalkan seperti dengan cara melindungi privasi, menjaga etika dalam berkomunikasi, hindari penyebaran SARA dan pornogafi, mengapresiasi karya orang lain, lebih seksama dalam menanggapi berita yang beredar, maupun hal yang lain yang bisa diupayakan. 


\section{UCAPAN TERIMA KASIH}

Terima kasih kepada pihak-pihak yang telah berkenan membantu dalam proses penelitian ini. Semoga hasil penelitian ini dapat membuahkan manfaat dan mampu dikembangkan lagi.

\section{DAFTAR PUSTAKA}

[1] Rulli, Nasrullah. Media Sosial; Persfektif Komunikasi, Budaya, dan Sosioteknologi. Bandung: Simbiosa Rekatama Media. 2015.

[2] Danis, Puntoadi. Menciptakan Penjualan melalui sosial media. Jakarta: Elex Media Komputindo. 2011.

[3] Rulli, Nasrullah. Media Sosial; Persfektif Komunikasi, Budaya, dan Sosioteknologi. Bandung: Simbiosa Rekatama Media. 2015.

[4] Widodo, Hendro Manajemen Pendidikan Sekolah, Madrasah, Pesantren. Bandung: PT Remaja Rosdakarya. 2020.

[5] Widodo, Hendro Manajemen Pendidikan Sekolah, Madrasah, Pesantren. Bandung: PT Remaja Rosdakarya. 2020.

[6] Lawang, Robert. Buku Materi Pokok Pengantar Sosiologi. Jakarta: Universitas Terbuka. 1994.

[7] Zarella, The Social Media Marketing Book, Oreilly Media: USA, 2010.

[8] Michael Haenlein, User of the word, unite! The challenges and oppoetunities of Sosial Media, Bussines Horizonz, 2020.

[9] Rulli Nasrullah, Media Sosial: Perspektif Komunikasi, Budaya, dan Sosioteknologi, Bandung: Remaja Rosydakarya, 2017.

[10] Tim Pusat Humas Kementrian Perdagangan RI, Panduan Optimalisasi Media Sosial Untuk Kementrian Perdagangan RI, Jakarta: Rusat Humas Kementrian Perdagangan RI, 2014.

[11] Rulli Nasrullah, Media Sosial: Perspektif Komunikasi, Budaya, dan Sosioteknologi, Bandung: Remaja Rosydakarya, 2017.

[12] Hilda Tenia, Pengertian Media Sosial-Fungsi, Ciri, Jenis, Dampak Positif, dan Dampak Negatif, 2017.

[13] Denis McQuail, Teori Komunikasi Massa Suatu Pengantar. Jakarta: Erlangga, 1992

[14] Arif Rahman \& Zalik Nuryana, Pendidikan Islam di Era Revolusi Industri 4.0, Yogyakarta: Komojoyo Press, 2019.

[15] Elly M. Setiadi dan Usman Kolip, Pengantar Sosiologi Pemahaman Fakta dan Gejala Permasalahan Sosial: Teori, Aplikasi dan Pemecahannya. Jakarta: Kencana Prenada Media Group, 2011.

[16] Irving M. Zeitlin. Memahami Kembali Sosiologi. Yogyakarta: Gajah Mada University Press, 1998.

[17] Kamus besar bahasa Indonesia. Jakarta: Balai Pustaka, 2005.

[18] Soerjono Soekanto, Sosiologi Suatu Pengantar. Jakarta: Rajawali Pers, 1992.

[19] Hamidi. 2010. Teori Komunikasi dan Strategi Dakwah. Malang: UMM Press.

[20] Ivan Fauzani Raharja, "Bijak Menggunakan Media Sosial Di Kalangan Pelajar Menurut Undang-undang Nomor 19 Tahun 2016 Tentang Informasi dan Transaksi Elektronik", dalam jurnal selat,vol.6, nomor 2, Mei 2019.

[21] Anang Sugeng Cahyono, "Pengaruh Media Sosial Terhadap Perubahan Sosial Masyarakat Indonesia" dalam jurnalnya.

[22] Fahmi Anwar, "Perubahan dan Permasalahan Media Sosial", dalam jurnal Perubahan dan Permasalahan Media Sosial, vol. 1, No. 1, April 2017.

[23] Fahmi Anwar, "Perubahan dan Permasalahan Media Sosial", dalam jurnal Perubahan dan Permasalahan Media Sosial, vol. 1, No. 1, April 2017. 